\title{
The role of alpha-7 nicotinic receptors in food intake behaviors
}

\author{
Kristina L. McFadden ${ }^{1}$, Marc-Andre Cornier ${ }^{2}$ and Jason R. Tregellas ${ }^{1,3}$ * \\ 1 Department of Psychiatry, School of Medicine, University of Colorado - Anschutz Medical Campus, Aurora, CO, USA \\ 2 Division of Endocrinology, Metabolism and Diabetes, Department of Medicine, School of Medicine, University of Colorado-Anschutz Medical Campus, \\ Aurora, CO, USA \\ ${ }^{3}$ Research Service, Veterans Affairs Medical Center, Denver, CO, USA
}

\section{Edited by:}

Tanya Zilberter, Infotonic Conseil, France

\section{Reviewed by:}

Marina Picciotto, Yale University, USA

Gudrun Sproesser, University of

Konstanz, Germany

${ }^{*}$ Correspondence:

Jason R. Tregellas, Department of Psychiatry, School of Medicine,

University of Colorado - Anschutz Medical Campus, 13001 East 17th

Place, Mail Stop F546, Aurora,

CO 80045, USA

e-mail: jason.tregellas@ucdenver.edu
Nicotine alters appetite and energy expenditure, leading to changes in body weight. While the exact mechanisms underlying these effects are not fully established, both central and peripheral involvement of the alpha-7 nicotinic acetylcholine receptor ( $\alpha 7 \mathrm{nAChR}$ ) has been suggested. Centrally, the $\alpha 7 n A C h R$ modulates activity of hypothalamic neurons involved in food intake regulation, including proopiomelanocortin and neuropeptide Y. $\alpha$ 7nAChRs also modulate glutamatergic and dopaminergic systems controlling reward processes that affect food intake. Additionally, $\alpha 7 n A C h R s$ are important peripheral mediators of chronic inflammation, a key contributor to health problems in obesity. This review focuses on nicotinic cholinergic effects on eating behaviors, specifically those involving the $\alpha 7 n A C h R$, with the hypothesis that $\alpha 7 n A C h R$ agonism leads to appetite suppression. Recent studies are highlighted that identify links between $\alpha 7 n A C h R$ expression and obesity, insulin resistance, and diabetes and describe early findings showing an $\alpha 7 n A C h R$ agonist to be associated with reduced weight gain in a mouse model of diabetes. Given these effects, the $\alpha 7 \mathrm{nAChR}$ may be a useful therapeutic target for strategies to treat and manage obesity.

Keywords: $\alpha 7$ nicotinic receptor, nicotine, obesity, eating behaviors, food intake

\section{INTRODUCTION}

Nicotine has long been known to affect energy balance and weight. Smokers, for example, weigh less than age- and sexmatched non-smokers (Albanes etal., 1987), while smoking cessation is associated with increased food intake and weight gain (Stamford et al., 1986; Williamson et al., 1991; Filozof et al., 2004). Given the strong link between smoking and reduced weight, many report using smoking for weight control, or avoid cessation due to fear of weight gain (Camp et al., 1993; Wiseman et al., 1998; Fulkerson and French, 2003). Experimentally, nicotine has been shown to suppress appetite, increase energy expenditure, and alter feeding patterns, which can lead to weight loss (Jo et al., 2002; Zoli and Picciotto, 2012). Despite these known effects, however, the mechanisms underlying nicotine's effects on eating behaviors and obesity remain unclear. Nicotine acts on both high-affinity nicotinic cholinergic receptors, such as the $\alpha 4-\beta 2$ receptor, and low-affinity receptors, such as the $\alpha 7$ receptor, both centrally and peripherally. Recent studies suggest that the alpha-7 nicotinic acetylcholine receptor $(\alpha 7 \mathrm{nAChR})$ may play a particularly prominent role in nicotinic effects on eating behaviors. As such, this review focuses on neuronal effects of nicotinic agents, especially those involving the $\alpha 7 \mathrm{nAChR}$, how stimulation of this receptor influences eating behaviors and weight, and the potential utility of $\alpha 7 \mathrm{nAChR}$ agonists as a novel treatment strategy for obesity.

\section{ALPHA-7 NICOTINIC ACETYLCHOLINE RECEPTORS}

Neuronal nicotinic acetylcholine receptors consist of ligand-gated ion channels that are activated by acetylcholine, but also respond to nicotine and similar compounds. These receptors are comprised of five transmembrane subunits arranged around a central pore (Paterson and Nordberg, 2000; Dani and Bertrand, 2007). These subunits include $\alpha \beta$ combinations ( $\alpha 2-\alpha 6$ and $\beta 2-\beta 4$ ), homomeric nAChRs $(\alpha 7-\alpha 9)$, and a heteromer $\alpha$ combination ( $\alpha 9$ with a10) (McGehee et al., 1995; Jones et al., 1999; Dani and Bertrand, 2007). The two main types of $n A C h R s$ found in the brain are $\alpha 4-\beta 2$ receptors and $\alpha 7$ receptors (Jensen et al., 2005; Changeux, 2010). While different $\mathrm{nAChR}$ subtypes may affect circuits involved in feeding behavior (Jo et al., 2002; Mineur et al., 2011a,b; Zoli and Picciotto, 2012), this review will focus on $\alpha 7 n A C h R s$, which are receiving increased research attention for their involvement in eating behaviors and food intake.

\section{CENTRAL EFFECTS OF $\alpha$ 7nAChRs ON EATING BEHAVIORS}

Previous reviews have described peripheral effects of nicotine and other $\alpha 7 \mathrm{nAChR}$ agonists on obesity and eating behaviors (Bencherif et al., 2011; Lakhan and Kirchgessner, 2011). As such, while recent evidence for peripheral effects will be briefly examined, the primary focus of this review will be on central effects. Overall, nicotine and other $\alpha 7 \mathrm{nAChR}$ agonists appear to suppress appetite through numerous complex, interacting central pathways, particularly those in the hypothalamus, which plays a fundamental role in energy balance. When various interactions are jointly considered, activation of hypothalamic $\alpha 7 \mathrm{nAChRs}$ is thought to result in overall increased inhibition of appetite circuits, resulting in decreased food intake (Jo et al., 2002). Stimulation of $\alpha 7 n A C h R s$ may also reduce food intake via effects on reward pathways or cortical networks involved in eating behaviors. 
$\alpha 7 n A C h R$ EFFECTS ON HYPOTHALAMIC NEUROPEPTIDES

Hypothalamic nuclei most associated with energy balance and feeding regulation include the lateral hypothalamus (LH), ventromedial hypothalamus (VMH), arcuate nucleus (ARC), and paraventricular nucleus (PVN). The LH is often simplistically described as the "hunger center" and the VMH the "satiety center" (Schwartz et al., 2000; Zoli and Picciotto, 2012). The ARC is a primary center for peripheral feeding signal integration (e.g., leptin, insulin) and contains neurons that stimulate feeding and those that inhibit feeding when activated, with projections to the PVN and LH (Schwartz et al., 2000; Kageyama et al., 2012; Zoli and Picciotto, 2012).

A primary potential pathway for $\alpha 7 \mathrm{nAChR}$ mediation of eating behaviors involves hypothalamic cholinergic input. The hypothalamus contains rich cholinergic innervation and some of the highest levels of $\alpha 7 \mathrm{nAChR}$ expression in the brain (Sargent, 1993). Appetite-related circuits within the hypothalamus can be modulated by $\mathrm{nAChR}$ activation, with a complex network of hormone and neuropeptide signals exerting neuronal effects to regulate eating behaviors. A number of studies have demonstrated effects of nicotine on these signals. Here, we will discuss $\alpha 7 \mathrm{nAChR}$ involvement in cholinergic effects on proopiomelanocortin (POMC), neuropeptide Y (NPY), and melanin-concentrating hormone $(\mathrm{MCH})$, all of which are involved in feeding regulation (Figure 1).

\section{POMC AND NPY}

Nicotine may suppress appetite via activation of POMC neurons. POMC is produced in the hypothalamus (Huang et al., 2011; Zoli and Picciotto, 2012) and is a precursor for melanocortins, such as $\alpha$-melanocyte-stimulating hormone ( $\alpha$-MSH), associated with suppressed food intake (Schwartz et al., 2000; Zoli and Picciotto, 2012). Electrophysiologically, Huang et al. (2011) demonstrated that nicotine excites mouse hypothalamic POMC neurons and that $\alpha 7 \mathrm{nAChRs}$ are present on these neurons. Nicotine effects were reduced by the $\alpha 7 \mathrm{nAChR}$ antagonist methyllycaconitine (MLA), suggesting at least partial mediation by $\alpha 7 n$ AChRs. As such, POMC stimulation is a potential mechanism through which $\alpha 7 \mathrm{nAChR}$ agonism may suppress appetite. It should be noted, however, that MLA is not as selective an antagonist for $\alpha 7 \mathrm{nAChRs}$ as $\alpha$-bungarotoxin (Klink et al., 2001; Mogg et al., 2002), which should be considered when MLA is used to assess $\alpha 7 \mathrm{nAChR}$ effects.

Neuropeptide Y, also produced in the hypothalamus, is associated with increased food intake (Schwartz et al., 2000). NPY neurons in the ARC project to the PVN to stimulate feeding (Morris, 1989; Kageyama et al., 2012). Thus, POMC and NPY have opposing effects on food intake. Smokers show reduced NPY levels compared to non-smokers, and smoking cessation is associated with increased NPY (Hussain et al., 2012), suggesting NPY inhibition as a mechanism for appetite suppression. However, nicotine effects on NPY are complex. As with POMC, NPY neurons in the hypothalamus are stimulated by nicotine and express $\alpha 7 n$ AChRs. Excitation of NPY neurons by nicotine is partially mediated by $\alpha 7 n A C h R s$, as MLA reduces excitation. Although nicotine reduces hypothalamic NPY mRNA in rats acutely (Frankish etal., 1995), NPY mRNA increases with chronic administration (Frankish et al., 1995; Li et al., 2000), which is accompanied by decreased food intake (Li et al., 2000). This is counterintuitive, as NPY stimulates food intake. However, nicotine also reduces hypothalamic NPY receptor density (Kane etal., 2001), which could explain the decreased intake. Another explanation for the net appetite-inhibiting effect of nicotine is that the depolarizing effect of nicotine on POMC neurons (anorexigenic) is significantly greater than that on NPY neurons (orexigenic). Furthermore, in addition to NPY neuron excitation

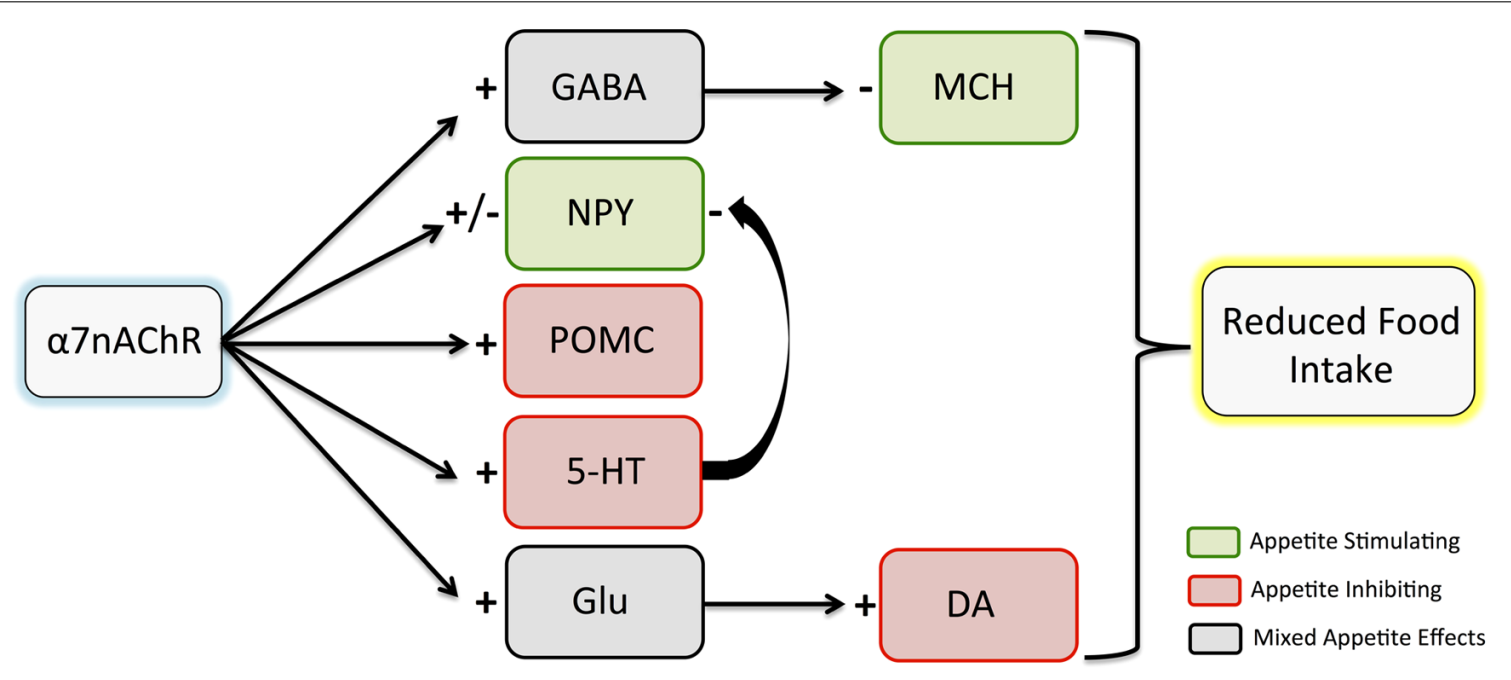

FIGURE 1 | Effects of $\alpha 7 n A C h R$ stimulation on hypothalamic neuropeptide and neurotransmitter release. Although there are complex interactions among pathways, it is hypothesized that the net effect of $\alpha 7 n A C h R$ stimulation leads to reduced food intake. Inhibitory effects are indicated with a minus sign, while excitatory effects are indicated with a plus sign. Note that both inhibitory and excitatory effects of $\alpha 7 n A C h R$ stimulation have been observed on NPY. While appetite effects of dopamine elsewhere in the brain are mixed, studies suggest that hypothalamic dopamine release contributes to appetite inhibition. $\alpha 7 n A C h R, \alpha 7$ nicotinic acetylcholine receptor; GABA, gamma aminobutyric acid; NPY, neuropeptide Y; POMC, proopiomelanocortin; 5-HT, serotonin; Glu, glutamate; $\mathrm{MCH}$, melanin-concentrating hormone; DA, dopamine. 
by nicotine, inhibition of excitatory synaptic activity (glutamate release) on NPY neurons was also observed, an effect not seen in POMC neurons (Huang et al., 2011). Thus, although nicotine can excite NPY neurons, the greater direct excitation of appetite-inhibiting POMC neurons compared to appetitestimulating NPY neurons, in addition to indirect inhibition of NPY neurons (via reduced glutamate release) may contribute to the net effect of appetite inhibition by nicotine and other $\alpha 7 \mathrm{nAChR}$ agonists.

\section{MELANIN-CONCENTRATING HORMONE}

Melanin-concentrating hormone $(\mathrm{MCH})$ neurons are primarily located in the LH (Zamir et al., 1986) and also stimulate food intake (Qu et al., 1996). MCH may have a particular role in reward-related aspects of food, as $\mathrm{MCH}$ neurons project to the nucleus accumbens (NAC) and the ventral tegmental area (VTA), brain areas involved in reward processes (Schilstrom et al., 1998; Jo et al., 2005). MCH knockout mice are excessively lean and demonstrate reduced food intake (Shimada et al., 1998; Marsh et al., 2002). a7nAChRs may mediate gamma aminobutyric acid (GABA)-related inhibition of $\mathrm{MCH}$ neurons in the LH, leading to this appetite suppression (Jo et al., 2005).

\section{$\alpha 7 n A C h R$ MODULATION OF NEUROTRANSMITTERS INVOLVED IN FOOD INTAKE BEHAVIORS}

In addition to hypothalamic neuropeptides, nicotine modulates effects of multiple other neurotransmitter systems in the brain. The following section describes the impact of nicotine on GABA, glutamate, dopamine (DA), and serotonin, focusing on how $\alpha 7 \mathrm{nAChRs}$ may inhibit appetite by modulating these neurotransmitter systems.

\section{GAMMA AMINOBUTYRIC ACID}

Release of GABA, the main inhibitory neurotransmitter in the brain, is influenced by nAChRs (McGehee etal., 1995; Jones et al., 1999). Nicotine effects on appetite reduction may be associated with decreased excitability of $\mathrm{MCH}$ neurons in the $\mathrm{LH}$ via increased GABAergic inhibitory tone. Jo et al. (2005) found nicotine administration to facilitate GABAergic transmission in adult mice, and prenatal nicotine exposure to enhance postnatal GABAergic transmission. Specific involvement of $\alpha 7 \mathrm{nAChRs}$

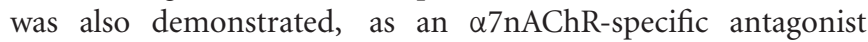
( $\alpha$-bungarotoxin) blocked these effects. As such, activation of $\alpha 7 \mathrm{nAChRs}$ on GABAergic terminals in the hypothalamus may contribute to the anorexigenic effects of nicotine.

\section{GLUTAMATE AND DOPAMINE}

Glutamate is the main excitatory neurotransmitter in the brain and plays a role in rewarding effects of nicotine, as nicotine increases glutamate release in the VTA and NAC, brain regions central to reward mechanisms (McGehee et al., 1995; Reid et al., 2000; Schilstrom et al., 2000). High concentrations of $\alpha 7 \mathrm{nAChRs}$ are observed in the VTA (Clarke and Pert, 1985; Dominguez del Toro et al., 1994; Schilstrom etal., 1998; Jones and Wonnacott, 2004) and are thought to mediate nicotineassociated glutamate release (McGehee et al., 1995; Schilstrom et al., 2000). $\alpha 7 \mathrm{nAChR}$-mediated glutamate release plays a large role in nicotine's effects on DA, a neurotransmitter critical in the reinforcing effects of nicotine (Schilstrom et al., 1998; Fowler et al., 2008). $\alpha 4-\beta 2$ nAChRs are sufficient for these reinforcing effects (Besson et al., 2012), likely via direct effects on DA neurons (Wooltorton et al., 2003; Besson et al., 2012). However, stimulation of $\alpha 7 \mathrm{nAChRs}$ activates DA neurons via glutamatergic inputs (Yoshida et al., 1992; Schilstrom et al., 2000, 2003; Garzon et al., 2013). Thus, $\alpha 7 n A C h R$ activation ultimately increases DA, but this is largely mediated via glutamatergic effects. Additionally, $\alpha 7 n A C h R s$ may be important in dopaminergic function following long-term nicotine exposure, as they are more resistant to desensitization at usual levels for smokers than nAChR subunits containing $\beta 2$ receptors, and may prevent dopaminergic hypoactivation resulting from chronic $\beta 2$ desensitization (Besson et al., 2007, 2012).

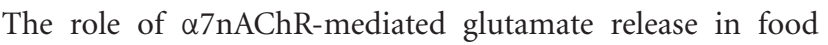
consumption remains unclear. Administration of a glutamate antagonist has been found to increase food intake in rats (Maldonado-Irizarry et al., 1995; Stratford et al., 1998). As such, glutamate release stimulated by an $\alpha 7 \mathrm{nAChR}$ agonist could decrease food intake. Increased DA release, amplified by $\alpha 7 \mathrm{nAChR}$-mediated glutamate release, increases the reward value of food (Yoshida et al., 1992; Schilstrom et al., 1998). Quarta et al. (2009) observed striatal DA release in mice following administration of an $\alpha 7 \mathrm{nAChR}$ agonist (choline), an effect not observed in mice lacking $\alpha 7 \mathrm{nAChRs}$. Food-induced DA release is attenuated by an $\alpha 7 \mathrm{nAChR}$ antagonist (MLA), implicating $\alpha 7 \mathrm{nAChRs}$ in eating-related reward (Schilstrom et al., 1998). However, the role of DA in feeding behaviors is complex and varies by brain region. Although DA contributes to rewarding aspects of food intake in areas such as the VTA and NAC, hypothalamic DA release is though to contribute to nicotine-related reductions in food intake (Meguid etal., 2000; Schwartz et al., 2000). Thus, further study is needed to determine if effects of $\alpha 7 \mathrm{nAChRs}$ on DA lead to overall increased or decreased consumption.

\section{SEROTONIN}

Serotonin inhibits food intake (Waldbillig etal., 1981; Jo et al., 2002), likely by promoting satiety (i.e., meal stopping; Shor-Posner etal., 1986). One mechanism may be via NPY, as evidence suggests serotonin inhibits NPY release (Dryden et al., 1995, 1996a,b). Nicotine-induced nAChR activation can increase serotonin release, contributing to appetite suppression (Summers

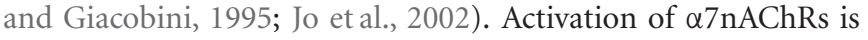
thought to influence serotonin release, as $\alpha 7 \mathrm{nAChRs}$ have been identified on serotonergic neurons (Galindo-Charles et al., 2008) and $\alpha 7 \mathrm{nAChR}$ stimulation increases serotonin release in the dorsal raphe nucleus (Li et al., 1998).

\section{CORTICAL $\alpha 7 n A C h R$ INVOLVEMENT IN FOOD INTAKE BEHAVIORS}

Cortically, $\alpha 7 n A C h R$ activation may affect limbic and paralimbic brain systems such as the insula and cingulate cortex, which also play a role in reward aspects of eating behaviors (Volkow et al., 2010) and contain rich cholinergic innervation (Nyback et al., 1989). 


\section{INSULA/SALIENCE NETWORK}

The insula, containing primary taste cortex, is involved in eating behavior regulation, including involvement in rewarding aspects of food and food-related arousal (Tataranni et al., 1999; Hinton etal., 2004; Cornier etal., 2009). The insula is also a central component of the salience network, an intrinsic brain network involved in assessing relevance of internal and external stimuli (Seeley et al., 2007; Bressler and Menon, 2010), in which altered response has been observed in obese, compared to lean, individuals (Garcia-Garcia et al., 2012; Kullmann et al., 2013). The insula is associated with urges and cravings related to both food and drugs of abuse (Pelchat et al., 2004; Naqvi and Bechara, 2009; Forget et al., 2010). Indeed, smokers sustaining insula damage following a stroke showed little subsequent difficulty quitting smoking, suggesting a role for the insula in effects of nicotine (Naqvi et al., 2007). However, the role of $\alpha 7 \mathrm{nAChRs}$ in the insula is not yet known. Via $\alpha$-bungarotoxin binding, studies have found $\alpha 7 \mathrm{nAChRs}$ in the insula in both rats (Fuchs, 1989) and monkeys (Han et al., 2003). Presence of $\alpha 7 \mathrm{nAChRs}$ in the human insula has been suggested by detection of $\alpha 7 \mathrm{nAChR}$ mRNA (Wevers, 2011), but insular $\alpha 7 \mathrm{nAChR}$ protein levels have not yet been studied in humans. As such, further study of $\alpha 7 \mathrm{nAChRs}$ in the insula, and how activation of these receptors relates to eating behaviors, is needed.

\section{POSTERIOR CINGULATE/DEFAULT MODE NETWORK}

The posterior cingulate cortex may also be involved in eating behaviors, having been associated with neuronal responses to visual food cues and taste (Tataranni et al., 1999; DelParigi et al., 2005; Cornier et al., 2009). The posterior cingulate is also a key component of the default mode network (DMN), an intrinsic brain network involved in self-referential thoughts and attention to internal stimuli (Buckner et al., 2008). DMN activity may play a role in eating behaviors, as overactivity of this network has been observed in obese, compared to lean, individuals (Tregellas et al., 2011a). Furthermore, this activity, which was associated with measures of appetite, was shown to change in response to feeding in lean, but not obese individuals. Nicotine can reduce resting-state DMN activity, including the posterior cingulate (Tanabe et al., 2011). $\alpha 7$ nAChRs are present in high concentrations in the cingulate cortex, as assessed by $\alpha$-bungarotoxin binding (Breese et al., 1997; Marutle et al., 2001). A study of DMN activity in schizophrenia patients observed reduced response following treatment with an $\alpha 7 \mathrm{nAChR}$ partial agonist [3-2,4dimethoxybenzylidene anabaseine (DMXB-A)], specifically in the posterior cingulate (Tregellas et al., 2011b). As with non-mentally ill obese individuals, DMN overactivity has been observed in schizophrenia patients (Garrity et al., 2007; Whitfield-Gabrieli et al., 2009), who are obese are rates twice those observed in the general population. Given these findings, it is possible that activation of $\alpha 7 \mathrm{nAChRs}$ could be a mechanism to normalize DMN hyperactivity in obesity.

\section{$\alpha 7 n A C h R s$ AND PERIPHERAL FACTORS INVOLVED IN EATING BEHAVIORS AND OBESITY}

Recent studies have discovered a key role for $\alpha 7 \mathrm{nAChRs}$ in peripheral factors related to obesity. In a mouse model of diabetes, Marrero etal. (2010) found that an $\alpha 7 n$ AChRselective agonist (TC-7020) reduced weight gain and food intake, as well as glucose and triglyceride levels and expression of proinflammatory cytokines. These effects were reversed by an $\alpha 7 \mathrm{nAChR}$ antagonist (MLA), supporting $\alpha 7 \mathrm{nAChR}$ involvement. In humans, Cancello et al. (2012) have also found evidence supporting $\alpha 7 \mathrm{nAChR}$ involvement in obesity. In addition to identifying $\alpha 7 \mathrm{nAChR}$ expression in human mature adipocytes, they found that expression was downregulated in obese compared to lean adults, and that weight loss partially restored $\alpha 7 \mathrm{nAChR}$ expression.

A potential mechanism through which peripheral $\alpha 7 \mathrm{nAChRs}$ may exert weight and food intake effects is by mediating antiinflammatory effects. Inflammation is a key feature of obesity, associated with increased proinflammatory cytokine production, insulin resistance, and development of type 2 diabetes (Marrero et al., 2010; Wang et al., 2011). Activation of $\alpha 7 n$ AChRs on cytokine-producing cells, such as macrophages, mediates this inflammatory response by inhibiting inflammatory cytokine production (Wang etal., 2011). A number of studies have demonstrated anti-inflammatory effects of nicotine (Wang et al., 2003; Lakhan and Kirchgessner, 2011) and smokers may have a reduced risk of some inflammatory diseases such as ulcerative colitis (Lakhan and Kirchgessner, 2011). The "cholinergic antiinflammatory pathway" can be activated by $\alpha 7 \mathrm{nAChR}$ agonists (Cheng et al., 2007). Supporting this, nicotine-induced cytokine inhibition can be blocked by $\alpha 7 \mathrm{nAChR}$-specific antagonists (Cheng et al., 2007), and $\alpha 7 \mathrm{nAChR}$ knockout mice show increased LPS-induced proinflammatory cytokine production, including TNF $\alpha$ and IL-1 $\beta$ (Wang etal., 2003). Wang et al. (2011) found adipose tissue and macrophages in mice to express $\alpha 7 \mathrm{nAChRs}$, and while nicotine suppressed proinflammatory cytokine production, this effect was not observed in $\alpha 7 n A C h R$ knockout mice. Additionally, nicotine reduced adipose tissue inflammation and improved insulin sensitivity in obese mice. Xu et al. (2012) observed improved insulin sensitivity in rodents following treatment with either nicotine or an $\alpha 7 \mathrm{nAChR}$ agonist (PNU-282987), an effect not observed in $\alpha 7 \mathrm{nAChR}$ knockout animals. These studies suggest that $\alpha 7 \mathrm{nAChRs}$ are critical in anti-inflammatory effects of nicotine. Given this, therapeutics targeting $\alpha 7 \mathrm{nAChRs}$ are increasingly being explored for diseases involving inflammation, such as diabetes, arthritis, and ulcerative colitis (Wang et al., 2003; Marrero etal., 2010; Bencherif et al., 2011; Lakhan and Kirchgessner, 2011).

\section{CONCLUSION}

The $\alpha 7 \mathrm{nAChR}$ plays an important role in both central and peripheral mechanisms involved in eating behaviors and energy balance. Studies have found links between $\alpha 7 \mathrm{nAChR}$ expression and obesity, insulin resistance, and diabetes. Centrally, $\alpha 7 \mathrm{nAChRs}$ modulate hypothalamic neuropeptides and neurotransmitters involved in feeding regulation and play a role in cortical processes affecting intake behavior. Overall, although the circuits involved are complex, it appears that net effects of nicotine and other $\alpha 7 \mathrm{nAChR}$ agonists result in appetite suppression, which could lead to weight loss. Peripherally, and perhaps also centrally, $\alpha 7 \mathrm{nAChRs}$ are also an important mediator of inflammation, a key contributor to health problems in obesity. 
Although $\alpha 7 \mathrm{nAChR}$ agonists have not yet been investigated for eating behavior effects in humans, preliminary animal work supports this idea, finding peripheral effects such as improved insulin sensitivity (Wang et al., 2011; Xu et al., 2012) and reduced weight gain and metabolic changes in a model of diabetes (Marrero et al., 2010). Further support for extending $\alpha 7 n A C h R$ studies to humans lies in the observation that $\alpha 7 \mathrm{nAChRs}$ are downregulated in human obesity, but normalize with weight loss (Cancello et al., 2012). In conclusion, given nicotine's effects in humans, experimental support for $\alpha 7 \mathrm{nAChR}$ involvement in eating behavior regulation, and early evidence of $\alpha 7 \mathrm{nAChR}$ agonist effects in animal studies, the $\alpha 7 \mathrm{nAChR}$ may represent a promising new therapeutic target for weight management and the treatment of obesity in humans.

\section{ACKNOWLEDGMENT}

Work on this manuscript was supported by NIH/NIDDK grant R01DK089095.

\section{REFERENCES}

Albanes, D., Jones, D. Y., Micozzi, M. S., and Mattson, M. E. (1987). Associations between smoking and body weight in the US population: analysis of NHANES II. Am. J. Public Health 77, 439-444. doi: 10.2105/AJPH.77.4.439

Bencherif, M., Lippiello, P. M., Lucas, R., and Marrero, M. B. (2011). Alpha7 nicotinic receptors as novel therapeutic targets for inflammation-based diseases. Cell. Mol. Life Sci. 68, 931-949. doi: 10.1007/s00018-010-0525-1

Besson, M., David, V., Baudonnat, M., Cazala, P., Guilloux, J. P., Reperant, C., et al. (2012). Alpha7-nicotinic receptors modulate nicotine-induced reinforcement and extracellular dopamine outflow in the mesolimbic system in mice. Psychopharmacology (Berl.) 220, 1-14. doi: 10.1007/s00213-011-2422-1

Besson, M., Granon, S., Mameli-Engvall, M., Cloez-Tayarani, I., Maubourguet, N., Cormier, A., et al. (2007). Long-term effects of chronic nicotine exposure on brain nicotinic receptors. Proc. Natl. Acad. Sci. U.S.A. 104, 8155-8160. doi: 10.1073/pnas.0702698104

Breese, C. R., Adams, C., Logel, J., Drebing, C., Rollins, Y., Barnhart, M., et al. (1997). Comparison of the regional expression of nicotinic acetylcholine receptor alpha7 mRNA and [125I]-alpha-bungarotoxin binding in human postmortem brain. J. Comp. Neurol. 387, 385-398. doi: 10.1002/(SICI)10969861(19971027)387:3<385::AID-CNE5>3.0.CO;2-X

Bressler, S. L., and Menon, V. (2010). Large-scale brain networks in cognition: emerging methods and principles. Trends Cogn. Sci. 14, 277-290. doi: 10.1016/j.tics.2010.04.004

Buckner, R. L., Andrews-Hanna, J. R., and Schacter, D. L. (2008). The brain's default network: anatomy, function, and relevance to disease. Ann. N. Y. Acad. Sci. 1124, 1-38. doi: 10.1196/annals.1440.011

Camp, D. E., Klesges, R. C., and Relyea, G. (1993). The relationship between body weight concerns and adolescent smoking. Health Psychol. 12, 24-32. doi: 10.1037/0278-6133.12.1.24

Cancello, R., Zulian, A., Maestrini, S., Mencarelli, M., Della Barba, A., Invitti, C., et al. (2012). The nicotinic acetylcholine receptor alpha7 in subcutaneous mature adipocytes: downregulation in human obesity and modulation by diet-induced weight loss. Int. J. Obes. (Lond.) 36, 1552-1557. doi: 10.1038/ijo.2011.275

Changeux, J. P. (2010). Nicotine addiction and nicotinic receptors: lessons from genetically modified mice. Nat. Rev. Neurosci. 11,389-401. doi: 10.1038/nrn2849

Cheng, P. Y., Lee, Y. M., Law, K. K., Lin, C. W., and Yen, M. H. (2007). The involvement of AMP-activated protein kinases in the anti-inflammatory effect of nicotine in vivo and in vitro. Biochem. Pharmacol. 74, 1758-1765. doi: 10.1016/j.bcp.2007.08.004

Clarke, P. B., and Pert, A. (1985). Autoradiographic evidence for nicotine receptors on nigrostriatal and mesolimbic dopaminergic neurons. Brain Res. 348, 355-358. doi: 10.1016/0006-8993(85)90456-1

Cornier, M. A., Salzberg, A. K., Endly, D. C., Bessesen, D. H., Rojas, D. C., and Tregellas, J. R. (2009). The effects of overfeeding on the neuronal response to visual food cues in thin and reduced-obese individuals. PLOS ONE 4:e6310. doi: 10.1371/journal.pone.0006310
Dani, J. A., and Bertrand, D. (2007). Nicotinic acetylcholine receptors and nicotinic cholinergic mechanisms of the central nervous system. Annu. Rev. Pharmacol. Toxicol. 47, 699-729. doi: 10.1146/annurev.pharmtox.47.120505.105214

DelParigi, A., Chen, K., Salbe, A. D., Reiman, E. M., and Tataranni, P. A. (2005). Sensory experience of food and obesity: a positron emission tomography study of the brain regions affected by tasting a liquid meal after a prolonged fast. Neuroimage 24, 436-443. doi: 10.1016/j.neuroimage.2004.08.035

Dominguez del Toro, E., Juiz, J. M., Peng, X., Lindstrom, J., and Criado, M. (1994). Immunocytochemical localization of the alpha 7 subunit of the nicotinic acetylcholine receptor in the rat central nervous system. J. Comp. Neurol. 349, 325-342. doi: $10.1002 / \mathrm{cne} .903490302$

Dryden, S., Frankish, H. M., Wang, Q., Pickavance, L., and Williams, G. (1996a). The serotonergic agent fluoxetine reduces neuropeptide $\mathrm{Y}$ levels and neuropeptide $\mathrm{Y}$ secretion in the hypothalamus of lean and obese rats. Neuroscience 72, 557-566. doi: 10.1016/0306-4522(95)00566-8

Dryden, S., Frankish, H. M., Wang, Q., and Williams, G. (1996b). Increased feeding and neuropeptide Y (NPY) but not NPY mRNA levels in the hypothalamus of the rat following central administration of the serotonin synthesis inhibitor p-chlorophenylalanine. Brain Res. 724, 232-237. doi: 10.1016/00068993(96)00329-0

Dryden, S., Wang, Q., Frankish, H. M., Pickavance, L., and Williams, G. (1995). The serotonin (5-HT) antagonist methysergide increases neuropeptide Y (NPY) synthesis and secretion in the hypothalamus of the rat. Brain Res. 699, 12-18. doi: 10.1016/0006-8993(95)00841-D

Filozof, C., Fernandez Pinilla, M. C., and Fernandez-Cruz, A. (2004). Smoking cessation and weight gain. Obes. Rev. 5, 95-103. doi: 10.1111/j.1467789X.2004.00131.x

Forget, B., Pushparaj, A., and Le Foll, B. (2010). Granular insular cortex inactivation as a novel therapeutic strategy for nicotine addiction. Biol. Psychiatry 68, 265-271. doi: 10.1016/j.biopsych.2010.01.029

Fowler, C. D., Arends, M. A., and Kenny, P. J. (2008). Subtypes of nicotinic acetylcholine receptors in nicotine reward, dependence, and withdrawal: evidence from genetically modified mice. Behav. Pharmacol. 19, 461-484. doi: 10.1097/FBP.0b013e32830c360e

Frankish, H. M., Dryden, S., Wang, Q., Bing, C., Macfarlane, I. A., and Williams, G. (1995). Nicotine administration reduces neuropeptide Y and neuropeptide Y mRNA concentrations in the rat hypothalamus: NPY may mediate nicotine's effects on energy balance. Brain Res. 694, 139-146. doi: 10.1016/0006-8993(95)00834-D

Fuchs, J. L. (1989). [125I]alpha-bungarotoxin binding marks primary sensory area developing rat neocortex. Brain Res. 501, 223-234. doi: 10.1016/00068993(89)90640-9

Fulkerson, J. A., and French, S. A. (2003). Cigarette smoking for weight loss or control among adolescents: gender and racial/ethnic differences. J. Adolesc. Health 32, 306-313. doi: 10.1016/S1054-139X(02)00566-9

Galindo-Charles, L., Hernandez-Lopez, S., Galarraga, E., Tapia, D., Bargas, J., Garduno, J., et al. (2008). Serotoninergic dorsal raphe neurons possess functional postsynaptic nicotinic acetylcholine receptors. Synapse 62, 601-615. doi: $10.1002 /$ syn.20526

Garcia-Garcia, I., Jurado, M. A., Garolera, M., Segura, B., Sala-Llonch, R., MarquesIturria, I., et al. (2012). Alterations of the salience network in obesity: a restingstate fMRI study. Hum. Brain Mapp. 34, 2786-2797. doi: 10.1002/hbm.22104

Garrity, A. G., Pearlson, G. D., Mckiernan, K., Lloyd, D., Kiehl, K. A., and Calhoun, V. D. (2007). Aberrant "default mode" functional connectivity in schizophrenia. Am. J. Psychiatry 164, 450-457. doi: 10.1176/appi.ajp.164.3.450

Garzon, M., Duffy, A. M., Chan, J., Lynch, M. K., Mackie, K., and Pickel, V. M. (2013). Dopamine $\mathrm{D}(2)$ and acetylcholine alpha7 nicotinic receptors have subcellular distributions favoring mediation of convergent signaling in the mouse ventral tegmental area. Neuroscience 252, 126-143. doi: 10.1016/j.neuroscience.2013.08.008

Han, Z. Y., Zoli, M., Cardona, A., Bourgeois, J. P., Changeux, J. P., and Le Novere, N. (2003). Localization of $[3 \mathrm{H}]$ nicotine, $[3 \mathrm{H}]$ cytisine, $[3 \mathrm{H}]$ epibatidine, and [125I] alpha-bungarotoxin binding sites in the brain of Macaca mulatta. J. Comp. Neurol. 461, 49-60. doi: 10.1002/cne.10659

Hinton, E. C., Parkinson, J. A., Holland, A. J., Arana, F. S., Roberts, A. C., and Owen, A. M. (2004). Neural contributions to the motivational control of appetite in humans. Eur. J. Neurosci. 20, 1411-1418. doi: 10.1111/j.1460-9568.2004. 03589.x 
Huang, H., Xu, Y., and Van Den Pol, A. N. (2011). Nicotine excites hypothalamic arcuate anorexigenic proopiomelanocortin neurons and orexigenic neuropeptide Y neurons: similarities and differences. J. Neurophysiol. 106, 1191-1202. doi: 10.1152/jn.00740.2010

Hussain, T., Al-Daghri, N. M., Al-Attas, O. S., Draz, H. M., Abd Al-Rahman, S. H., and Yakout, S. M. (2012). Plasma neuropeptide Y levels relate cigarette smoking and smoking cessation to body weight regulation. Regul. Pept. 176, 22-27. doi 10.1016/j.regpep.2012.02.005

Jensen, A. A., Frolund, B., Liljefors, T., and Krogsgaard-Larsen, P. (2005). Neuronal nicotinic acetylcholine receptors: structural revelations, target identifications, and therapeutic inspirations. J. Med. Chem. 48, 4705-4745. doi: 10.1021/jm040219e

Jones, I. W., and Wonnacott, S. (2004). Precise localization of alpha7 nicotinic acetylcholine receptors on glutamatergic axon terminals in the rat ventral tegmental area. J. Neurosci. 24, 11244-11252. doi: 10.1523/JNEUROSCI.3009-04.2004

Jones, S., Sudweeks, S., and Yakel, J. L. (1999). Nicotinic receptors in the brain: correlating physiology with function. Trends Neurosci. 22, 555-561. doi: 10.1016/S0166-2236(99)01471-X

Jo, Y. H., Talmage, D. A., and Role, L. W. (2002). Nicotinic receptor-mediated effects on appetite and food intake. J. Neurobiol. 53, 618-632. doi: 10.1002/neu.10147

Jo, Y. H., Wiedl, D., and Role, L. W. (2005). Cholinergic modulation of appetiterelated synapses in mouse lateral hypothalamic slice. J. Neurosci. 25, 11133-11144. doi: 10.1523/JNEUROSCI.3638-05.2005

Kageyama, H., Takenoya, F., Hirako, S., Wada, N., Kintaka, Y., Inoue, S., et al. (2012). Neuronal circuits involving neuropeptide $Y$ in hypothalamic arcuate nucleus-mediated feeding regulation. Neuropeptides 46, 285-289. doi: 10.1016/j.npep.2012.09.007

Kane, J. K., Parker, S. L., and Li, M. D. (2001). Hypothalamic orexin-A binding sites are downregulated by chronic nicotine treatment in the rat. Neurosci. Lett. 298 , 1-4. doi: 10.1016/S0304-3940(00)01730-4

Klink, R., De Kerchove D’Exaerde, A., Zoli, M., and Changeux, J. P. (2001). Molecular and physiological diversity of nicotinic acetylcholine receptors in the midbrain dopaminergic nuclei. J. Neurosci. 21, 1452-1463.

Kullmann, S., Pape, A. A., Heni, M., Ketterer, C., Schick, F., Haring, H. U., et al. (2013). Functional network connectivity underlying food processing: disturbed salience and visual processing in overweight and obese adults. Cereb. Cortex 23, 1247-1256. doi: 10.1093/cercor/bhs124

Lakhan, S. E., and Kirchgessner, A. (2011). Anti-inflammatory effects of nicotine in obesity and ulcerative colitis. J. Transl. Med. 9:129. doi: 10.1186/1479-5876-9-129

Li, M. D., Kane, J. K., Parker, S. L., Mcallen, K., Matta, S. G., and Sharp, B. M. (2000). Nicotine administration enhances NPY expression in the rat hypothalamus. Brain Res. 867, 157-164. doi: 10.1016/S0006-8993(00)02283-6

Li, X., Rainnie, D. G., Mccarley, R. W., and Greene, R. W. (1998). Presynaptic nicotinic receptors facilitate monoaminergic transmission. J. Neurosci. 18, 19041912.

Maldonado-Irizarry, C. S., Swanson, C. J., and Kelley, A. E. (1995). Glutamate receptors in the nucleus accumbens shell control feeding behavior via the lateral hypothalamus. J. Neurosci. 15, 6779-6788.

Marrero, M. B., Lucas, R., Salet, C., Hauser, T. A., Mazurov, A., Lippiello, P. M. et al. (2010). An alpha7 nicotinic acetylcholine receptor-selective agonist reduces weight gain and metabolic changes in a mouse model of diabetes. J. Pharmacol. Exp. Ther. 332, 173-180. doi: 10.1124/jpet.109.154633

Marsh, D. J., Weingarth, D. T., Novi, D. E., Chen, H. Y., Trumbauer, M. E., Chen, A. S., et al. (2002). Melanin-concentrating hormone 1 receptor-deficient mice are lean, hyperactive, and hyperphagic and have altered metabolism. Proc. Natl. Acad. Sci. U.S.A. 99, 3240-3245. doi: 10.1073/pnas.052706899

Marutle, A., Zhang, X., Court, J., Piggott, M., Johnson, M., Perry, R., et al. (2001). Laminar distribution of nicotinic receptor subtypes in cortical regions in schizophrenia. J. Chem. Neuroanat. 22, 115-126. doi: 10.1016/S08910618(01)00117-X

McGehee, D. S., Heath, M. J., Gelber, S., Devay, P., and Role, L. W. (1995). Nicotine enhancement of fast excitatory synaptic transmission in CNS by presynaptic receptors. Science 269, 1692-1696. doi: 10.1126/science.7569895

Meguid, M. M., Fetissov, S. O., Varma, M., Sato, T., Zhang, L., Laviano, A., et al. (2000). Hypothalamic dopamine and serotonin in the regulation of food intake. Nutrition 16, 843-857. doi: 10.1016/S0899-9007(00)00449-4

Mineur, Y. S., Abizaid, A., Rao, Y., Salas, R., Dileone, R. J., Gundisch, D., et al. (2011a). Nicotine decreases food intake through activation of POMC neurons. Science 332, 1330-1332. doi: 10.1126/science.1201889
Mineur, Y. S., Einstein, E. B., Seymour, P. A., Coe, J. W., O’Neill, B. T., Rollema, H., et al. (2011b). alpha4beta2 nicotinic acetylcholine receptor partial agonists with low intrinsic efficacy have antidepressant-like properties. Behav. Pharmacol. 22, 291-299. doi: 10.1097/FBP.0b013e328347546d

Mogg, A. J., Whiteaker, P., Mcintosh, J. M., Marks, M., Collins, A. C., and Wonnacott, S. (2002). Methyllycaconitine is a potent antagonist of alpha-conotoxin-MII-sensitive presynaptic nicotinic acetylcholine receptors in rat striatum. J. Pharmacol. Exp. Ther. 302, 197-204. doi: 10.1124/jpet. 302.1.197

Morris, B. J. (1989). Neuronal localisation of neuropeptide Y gene expression in rat brain. J. Comp. Neurol. 290, 358-368. doi: 10.1002/cne.902900305

Naqvi, N. H., and Bechara, A. (2009). The hidden island of addiction: the insula. Trends Neurosci. 32, 56-67. doi: 10.1016/j.tins.2008.09.009

Naqvi, N. H., Rudrauf, D., Damasio, H., and Bechara, A. (2007). Damage to the insula disrupts addiction to cigarette smoking. Science 315, 531-534. doi: $10.1126 /$ science.1135926

Nyback, H., Nordberg, A., Langstrom, B., Halldin, C., Hartvig, P., Ahlin, A., et al. (1989). Attempts to visualize nicotinic receptors in the brain of monkey and man by positron emission tomography. Prog. Brain Res. 79, 313-319. doi: 10.1016/S0079-6123(08)62490-5

Paterson, D., and Nordberg, A. (2000). Neuronal nicotinic receptors in the human brain. Prog. Neurobiol. 61, 75-111. doi: 10.1016/S0301-0082(99)00045-3

Pelchat, M. L., Johnson, A., Chan, R., Valdez, J., and Ragland, J. D. (2004). Images of desire: food-craving activation during fMRI. Neuroimage 23, 1486-1493. doi: 10.1016/j.neuroimage.2004.08.023

Quarta, D., Naylor, C. G., Barik, J., Fernandes, C., Wonnacott, S., and Stolerman, I. P. (2009). Drug discrimination and neurochemical studies in alpha7 null mutant mice: tests for the role of nicotinic alpha7 receptors in dopamine release. Psychopharmacology (Berl.) 203, 399-410. doi: 10.1007/s00213-008-1281-x

Qu, D., Ludwig, D. S., Gammeltoft, S., Piper, M., Pelleymounter, M. A., Cullen, M. J., et al. (1996). A role for melanin-concentrating hormone in the central regulation of feeding behaviour. Nature 380, 243-247. doi: 10.1038/380243a0

Reid, M. S., Fox, L., Ho, L. B., and Berger, S. P. (2000). Nicotine stimulation of extracellular glutamate levels in the nucleus accumbens: neuropharmacological characterization. Synapse 35, 129-136. doi: 10.1002/(SICI)10982396(200002)35:2<129::AID-SYN5>3.0.CO;2-D

Sargent, P. B. (1993). The diversity of neuronal nicotinic acetylcholine receptors. Annu. Rev. Neurosci. 16, 403-443. doi: 10.1146/annurev.ne.16.030193.002155

Schilstrom, B., Fagerquist, M. V., Zhang, X., Hertel, P., Panagis, G., Nomikos, G. G., etal. (2000). Putative role of presynaptic alpha7* nicotinic receptors in nicotine stimulated increases of extracellular levels of glutamate and aspartate in the ventral tegmental area. Synapse 38, 375-383. doi: 10.1002/10982396(20001215)38:4<375::AID-SYN2>3.0.CO;2-Y

Schilstrom, B., Rawal, N., Mameli-Engvall, M., Nomikos, G. G., and Svensson, T. H. (2003). Dual effects of nicotine on dopamine neurons mediated by different nicotinic receptor subtypes. Int. J. Neuropsychopharmacol. 6, 1-11. doi: $10.1017 /$ S1461145702003188

Schilstrom, B., Svensson, H. M., Svensson, T. H., and Nomikos, G. G. (1998). Nicotine and food induced dopamine release in the nucleus accumbens of the rat: putative role of alpha7 nicotinic receptors in the ventral tegmental area. Neuroscience 85, 1005-1009. doi: 10.1016/S0306-4522(98)00114-6

Schwartz, M. W., Woods, S. C., Porte, D. Jr., Seeley, R. J., and Baskin, D. G. (2000). Central nervous system control of food intake. Nature 404, 661-671. doi: $10.1038 / 35007534$

Seeley, W. W., Menon, V., Schatzberg, A. F., Keller, J., Glover, G. H., Kenna, H., et al. (2007). Dissociable intrinsic connectivity networks for salience processing and executive control. J. Neurosci. 27, 2349-2356. doi: 10.1523/JNEUROSCI.558706.2007

Shimada, M., Tritos, N. A., Lowell, B. B., Flier, J. S., and Maratos-Flier, E. (1998). Mice lacking melanin-concentrating hormone are hypophagic and lean. Nature 396, 670-674. doi: 10.1038/25341

Shor-Posner, G., Grinker, J. A., Marinescu, C., Brown, O., and Leibowitz, S. F. (1986). Hypothalamic serotonin in the control of meal patterns and macronutrient selection. Brain Res. Bull. 17, 663-671. doi: 10.1016/0361-9230(86) 90198-X

Stamford, B. A., Matter, S., Fell, R. D., and Papanek, P. (1986). Effects of smoking cessation on weight gain, metabolic rate, caloric consumption, and blood lipids. Am. J. Clin. Nutr. 43, 486-494. 
Stratford, T. R., Swanson, C. J., and Kelley, A. (1998). Specific changes in food intake elicited by blockade or activation of glutamate receptors in the nucleus accumbens shell. Behav. Brain Res. 93, 43-50. doi: 10.1016/S0166-4328(97)00140-X

Summers, K. L., and Giacobini, E. (1995). Effects of local and repeated systemic administration of (-)nicotine on extracellular levels of acetylcholine, norepinephrine, dopamine, and serotonin in rat cortex. Neurochem. Res. 20, 753-759. doi: 10.1007/BF01705545

Tanabe, J., Nyberg, E., Martin, L. F., Martin, J., Cordes, D., Kronberg, E., et al. (2011). Nicotine effects on default mode network during resting state. Psychopharmacology (Berl.) 216, 287-295. doi: 10.1007/s00213-011-2221-8

Tataranni, P. A., Gautier, J. F., Chen, K., Uecker, A., Bandy, D., Salbe, A. D., et al. (1999). Neuroanatomical correlates of hunger and satiation in humans using positron emission tomography. Proc. Natl. Acad. Sci. U.S.A. 96, 4569-4574. doi: 10.1073/pnas.96.8.4569

Tregellas, J. R., Wylie, K. P., Rojas, D. C., Tanabe, J., Martin, J., Kronberg, E., et al. (2011a). Altered default network activity in obesity. Obesity (Silver Spring) 19, 2316-2321. doi: 10.1038/oby.2011.119

Tregellas, J. R., Tanabe, J., Rojas, D. C., Shatti, S., Olincy, A., Johnson, L., et al. (2011b). Effects of an alpha 7-nicotinic agonist on default network activity in schizophrenia. Biol. Psychiatry 69, 7-11. doi: 10.1016/j.biopsych.2010.07.004

Volkow, N. D., Wang, G. J., Fowler, J. S., Tomasi, D., Telang, F., and Baler, R. (2010). Addiction: decreased reward sensitivity and increased expectation sensitivity conspire to overwhelm the brain's control circuit. Bioessays 32, 748-755. doi: 10.1002/bies.201000042

Waldbillig, R. J., Bartness, T. J., and Stanley, B. G. (1981). Increased food intake, body weight, and adiposity in rats after regional neurochemical depletion of serotonin. J. Comp. Physiol. Psychol. 95, 391-405. doi: 10.1037/h0077790

Wang, H., Yu, M., Ochani, M., Amella, C. A., Tanovic, M., Susarla, S., et al. (2003). Nicotinic acetylcholine receptor alpha7 subunit is an essential regulator of inflammation. Nature 421, 384-388. doi: 10.1038/nature01339

Wang, X., Yang, Z., Xue, B., and Shi, H. (2011). Activation of the cholinergic antiinflammatory pathway ameliorates obesity-induced inflammation and insulin resistance. Endocrinology 152, 836-846. doi: 10.1210/en.2010-0855

Wevers, A. (2011). Localisation of pre- and postsynaptic cholinergic markers in the human brain. Behav. Brain Res. 221, 341-355. doi: 10.1016/j.bbr.2010.02.025

Whitfield-Gabrieli, S., Thermenos, H. W., Milanovic, S., Tsuang, M. T., Faraone, S. V., Mccarley, R. W., et al. (2009). Hyperactivity and hyperconnectivity of the default network in schizophrenia and in first-degree relatives of persons with schizophrenia. Proc. Natl. Acad. Sci. U.S.A. 106, 1279-1284. doi: 10.1073/pnas.0809141106
Williamson, D. F., Madans, J., Anda, R. F., Kleinman, J. C., Giovino, G. A., and Byers, T. (1991). Smoking cessation and severity of weight gain in a national cohort. $N$. Engl. J. Med. 324, 739-745. doi: 10.1056/NEJM199103143241106

Wiseman, C. V., Turco, R. M., Sunday, S. R., and Halmi, K. A. (1998). Smoking and body image concerns in adolescent girls. Int. J. Eat. Disord. 24, 429-433. doi: 10.1002/(SICI)1098-108X(199812)24:4<429::AID-EAT10>3.0.CO;2-D

Wooltorton, J. R., Pidoplichko, V. I., Broide, R. S., and Dani, J. A. (2003). Differential desensitization and distribution of nicotinic acetylcholine receptor subtypes in midbrain dopamine areas. J. Neurosci. 23, 3176-3185.

Xu, T. Y., Guo, L. L., Wang, P., Song, J., Le, Y. Y., Viollet, B., et al. (2012), Chronic exposure to nicotine enhances insulin sensitivity through alpha7 nicotinic acetylcholine receptor-STAT3 pathway. PLOS ONE 7:e51217. doi: 10.1371/journal.pone.0051217

Yoshida, M., Yokoo, H., Mizoguchi, K., Kawahara, H., Tsuda, A., Nishikawa, T., et al. (1992). Eating and drinking cause increased dopamine release in the nucleus accumbens and ventral tegmental area in the rat: measurement by in vivo microdialysis. Neurosci. Lett. 139, 73-76. doi: 10.1016/0304-3940(92)90861-Z

Zamir, N., Skofitsch, G., Bannon, M. J., and Jacobowitz, D. M. (1986). Melanin-concentrating hormone: unique peptide neuronal system in the rat brain and pituitary gland. Proc. Natl. Acad. Sci. U.S.A. 83, 1528-1531. doi: 10.1073/pnas.83.5.1528

Zoli, M., and Picciotto, M. R. (2012). Nicotinic regulation of energy homeostasis. Nicotine Tob. Res. 14, 1270-1290. doi: 10.1093/ntr/nts159

Conflict of Interest Statement: The authors declare that the research was conducted in the absence of any commercial or financial relationships that could be construed as a potential conflict of interest.

Received: 24 February 2014; accepted: 19 May 2014; published online: 06 June 2014. Citation: McFadden KL, Cornier MA and Tregellas JR (2014) The role of alpha7 nicotinic receptors in food intake behaviors. Front. Psychol. 5:553. doi: 10.3389/fpsyg.2014.00553

This article was submitted to Eating Behavior, a section of the journal Frontiers in Psychology.

Copyright (C) 2014 McFadden, Cornier and Tregellas. This is an open-access article distributed under the terms of the Creative Commons Attribution License (CC BY). The use, distribution or reproduction in other forums is permitted, provided the original author(s) or licensor are credited and that the original publication in this journal is cited, in accordance with accepted academic practice. No use, distribution or reproduction is permitted which does not comply with these terms. 